\title{
Strengthening on Human Resources Investment through Education in Indonesia
}

\author{
Muhammad Nuril Huda \\ Department of Educational Management \\ Universitas Negeri Surabaya \\ Surabaya, Indonesia \\ e-mail: real_bjn80@yahoo.com
}

\begin{abstract}
The implications of globalization are the increasing of competition among countries caused by the opening of crosscountry information, goods, services and capital flows. Globalization is also quite vulnerable to dragging on the phenomenon of moral decline, which often collides with national ethics and character. Human resources are a key factor to be able to guard the flow of competition and become a national moral stronghold in the space of globalization. In this context, education system in Indonesia is an important part to be able to develop the potential of human resources, through capacity building and forming national character. Therefore, the state must be able to place education as part of a national strategy in facing the globalization era. This paper describes how the positioning of education as a process of investing human resources in the framework of facing global competition.
\end{abstract}

Keywords-human resources; investment; education

\section{INTRODUCTION}

Globalization will have a significant impact on various dimensions of life. According to Faith [1], the era of globalization will be accompanied by various differences and social changes that are very unpredictable, while the inability to calculate what will happen. This requires an increase in better human resources. Change itself is supported by three factors, namely: the development of science and technology, population, and ecological or environmental factors.

Global flows must be accompanied by a paradigm shift in the development of human resources in each country, as a logical means to be able to compete with other countries. The front guard of the competition in the global era focuses on human resource capacity, both in mastering knowledge and technology, as well as diploma skills in the global political context.

Human capital is needed to support economic activities in each region for progress. The country's ability to develop its human resources, specifically providing talented jobs in various fields, is the key to success in every country [2]. Development of human resource capacity as a form of longterm capital investment, the process of value and knowledge transfer that leads to the world education aspect.

Education is essentially an effort to inherit value, which will be a helper and determinant of humanity in the struggle for life. The progress of the decline or the poor of civilization, will be determined by the education undertaken by the community [3]. The educational aspect as a manifestation of the country's development investment has become a fulcrum for obtaining the quality and capability of human resources who are ready to compete in adapting to the globalization flow. This readiness is not only in the realm of knowledge and skills, but also in the integrity of character in stemming moral decadence.

\section{THE CONCEPT OF HuMAN RESOURCE INVESTMENT}

Investment is often referred to as the term physical capital, which deals with the world of finance and economics. Investment is defined as planting money or capital in a company or project for the purpose of making a profit. These investments are related to the accumulation of an asset form with an expectation of getting a profit in the future. Investment as a form of investment can be physical, such as goods or infrastructure, also can be in the form of non-physical, such as education, training or employment. Investment activity is an important variable in the development process, because through investment it will become capital to realize the ideals of a nation and country. One form of non-physical investment is the education process as an investment activity in human resources.

The concept of human resources investment is that people possess skills, experience, and knowledge that have economic value. Although the theory was originally developed to study the economic value of education, more recently it has been applied to selection, training, compensation and human resource management [4]. Investment in human resources is a number of funds issued and opportunities to earn income during the investment process. Investment in human resources in developing countries is very necessary, even if it is macro and long-term, because the benefits are only felt after several decades [5]. In the long term, improving the quality of human resources will spur the efficiency and productivity of development in a country.

The history of several countries has shown the importance of the role of human resources in building the progress of their country, despite experiencing limitations in natural resources. Investment in human resources is a key role in encouraging other production factors, such as: land, labor, and infrastructure. The capacity of human resources, in the dimensions of knowledge, skills and attitudes, will be able to 
sustain the structuring of the economic, cultural, political and national security systems.

Investment in human resources can encourage the quality of competitiveness in the face of the rapidly developing information technology era. The results of research by the World Bank show that there is a difference in economic growth of $1.25 \%$ of gross domestic product in the period 1991-2016, between $25 \%$ of countries that human resources investment with $25 \%$ of countries that do little or not at all. The results of the study show that investment in human resources has a major impact on economic growth.

\section{EDUCATION AS AN INVESTMENT IN HUMAN RESOURCES}

The concept of education as an investment has developed for a long time which is believed that the development of the education sector in a country is an important factor that drives growth in other development sectors. Human resources reflect investment in education, development of specific competencies and skills, which are needed to carry out certain economic activities [6]. According to Nurulfalik [7], the concept of investment in human capital (human capital investment) that can support economic growth, has actually begun to be considered before the 19th century since the time of Adam Smith in 1776 and Heinrich von Thunen in 1875. Investment in this period emphasized the importance of investment in the form of human skills.

The development of new thinking about human resource investment took an important milestone in the 1960s when Theodore Schultz, who was the foundation of the theory of modern human capital, addressed the title "Investment in Human Capital" in the presence of The American Economic Association. According to Schultz, the process of acquiring knowledge and skills through education is not merely a form of consumption, but also an investment. Schultz shows that the development of the education sector that focuses on human resources has contributed directly to the economic growth of a country, through increasing skills and the ability to produce labor [8].

Human capital is indeed a series of cognitive abilities that are inherent in humans productively, cannot be seen in a short time, but in the long run has a strong influence in increasing the productivity of human resources. According to Adam Smith, as quoted by Nurjanah [9], that human capital is the ability and skills obtained through education, independent learning, learning by doing, and for that it requires a fee for the concerned. Skills and abilities will produce a high rate of return on one's income. In the human capital approach, there is a linear relationship between educational investment and high human productivity.

The relation between education and community development is inseparable from one another. The progress of a society and nation is very much determined by the development of the education sector in preparing human resources in accordance with the times [10]. The economy of a country is also influenced by the quality of its human resources. A country will be able to develop if its human resources have strong capacity and integrity, both from the aspects of ethics, morality, responsibility, commitment, honesty, and placing rights and obligations as a proportionate nation. The quality of human resources is an indicator of the success of a quality education system. Even so, education certainly is not only seen as an economic investment but also needs to be seen from the social, cultural dimensions within the framework of human values.

Educational investment in social-humanitarian functions refers to the contribution of education to human development and social relations at various different social levels. For example, at the individual level, education helps students develop themselves prolifically, socially, physically and helps students develop their potential to the fullest [11]. Through the contribution of education, individual students will be able to develop their own potential optimally, both cognitive, affective and psychomotor. If it is drawn in the context of society, increasing the capacity of human resources in the community will spur and trigger the overall capacity building of the nation. The logical implication will certainly encourage an increase in the bargaining value of human resources in a country in the space of global competition.

However, investment in human resources in education has several aspects that need to be assessed and calculated as success criteria, namely:

a. The direct economic value of an investment, namely the balance between opportunity costs and expected future profits through increasing labor productivity.

b. Indirect economic returns, namely external benefits that affect the income of other community members.

c. Fiscal benefits, namely an increase in state revenues and the tax sector caused by increased income for educated workers.

d. Meeting the needs of skilled and trained workforce.

e. Community demand for education.

f. Internal efficiency of the educational institution itself, namely the relationship between input and output as measured by indicators of waste, repetition, dropping out of school, and cost effectiveness.

g. The creation of a more even distribution of educational opportunities for all school-age residents.

h. Positive impact and equal distribution of educational opportunities on the distribution of income and the contribution of education to reducing poverty.

i. The link between investment in the education sector and investment in other sectors, including health, industry, agriculture. Human resources investment is reinforced by several research results that have proven the importance of education in supporting economic growth. Educational contributions to economic growth are stronger after taking into account the effects of transactions between education and other forms of physical investment [12].

The economic value of education can be seen and the contribution of benefits to socio-economic development through increasing knowledge, skills, attitudes and productivity. For the community, education is useful to improve the standard of living of the economy, politics and culture. Education strengthens the ability to use technology for advancement in the social and economic fields. Costs incurred in the field of education as a form of investment in a certain period of time, in the future must be able to produce benefits, 
both in the form of money (financial) and non-financial. In the form of money can be obtained from remuneration for labor productivity, while in the form of non-financial, such as improving health, security or public order.

There are two types of indicators that are used as references to assess the forms of investment benefits in education, namely: private rate of return and social rate of return. Private rate of return is intended to measure individual profits in spending costs on their own education, such as by measuring future income. This is directly related to educational needs and education funding. The social rate of return is related to the costs and benefits of education for the community as a whole. The social rate of return from the education sector comes in two forms, namely: education increases the productivity of the economy as a whole, and by creating an educated population, the government system will participate better [13].

Through consideration of the significance of investment in human resources through the improvement of the education sector, many countries place government spending that focuses on the education sector as a policy priority. The level of education expenses is an indicator of state financial efforts for investment from human capital resources and shows priority scale among other sectors in the state financial allocation posture. Of course, the achievement of targets through education investment is not seen in the near future, but is a long reach to foster national capacity and competitiveness.

\section{INVESTMENT IN HUMAN RESOURCES THROUGH EDUCATION IN INDONESIA}

The Indonesian government policy in encouraging investment and competitiveness of human resources through education is in line with the reality of Indonesia's human resource capacity that needs to be continuously improved. From the release of World Bank data in 2018 related to the Human Development Index (HDI) issued by the United Nations Development Program (UNDP) in the annual publication titled Human Development Report, Indonesia's position in 2017 is $116^{\text {th }}$ out of 189 countries. Indonesia scored 0.694 or still below the world average of 0.728 . Human development indicators are seen from the aspect of longevity as measured by life expectancy, education as measured by the average number of adults who can read and the average year of school years, as well as indicators of gross national income per capita [14].

With this score, Indonesia is in the Medium Human Development category, below Singapore, Brunei Darussalam, Malaysia and Thailand. Singapore, Brunei Darussalam and Malaysia are in the Very High Human Development category, respectively occupying positions $9^{\text {th }}, 39^{\text {th }}$ and $57^{\text {th }}$. While Thailand is in the category of High Human Development and sits at $83^{\text {rd }}$. While in the context of the World Bank version of the Human Capital Index, Indonesia ranked $87^{\text {th }}$ out of 157 countries. The four highest ranks are bought by Asian countries. Indonesia's position is worse than the five ASEAN countries, but it is better than the other three ASEAN countries.

While based on data from the Statistics Agency (BPS) released in April 2018, Indonesia's Human Development Index (HDI) in 2017 reached 70.81. This figure increased by 0.63 points or grew by 0.90 percent compared to 2016 . Babies born in 2017 have a life expectancy of up to 71.06 years, longer than 0.16 years compared to those born the previous year. Children who are 7 years old in 2017 have hopes of enjoying 12.85 years of education, 0.13 years longer than those of the same age in 2016. Meanwhile, residents aged 25 years and over are on average they have studied for 8.10 years, 0.15 years longer than the previous year. In 2017, the Indonesian people meet their needs with an average per capita expenditure of 10.66 million rupiahs per year, an increase of 244 thousand rupiahs compared to the previous year's expenditure [15].

Indonesia as one of the developing countries is trying to continue to place the education sector as a development priority. This commitment is in line with the Indonesian government's policy to increase the education budget. Through increasing education budget allocations, it is expected to boost Indonesia's human resource capacity in mastering science and technology. Besides that, to increase faith, piety and noble character in the framework of strengthening national character.

Budget priorities in the education sector in Indonesia have been juridical stated through the state legislative system. In the 1945 Constitution of the Republic of Indonesia, Article 31 states that the state shall prioritize the budget for education to a minimum of $20 \%$ of the state budget and of the regional budgets to fulfil the needs of implementation of national education. The contents of the article are the attitudes of the nation and state to prioritize the implementation of education as an effort to educate the nation's life and advance national culture. The 1945 Constitution of the Republic of Indonesia requires the government to pay for basic education and the obligation of citizens to attend the basic education, and the state prioritizes the education budget of at least $20 \%$ of the state budget and regional budget.

While in the Act Number 20 Year 2003 on the National Education System in Article 49 Paragraph 1, it is also emphasized that education funds other than educator salaries and official education costs are allocated at least $20 \%$ of the state budget in the education sector and at a minimum $20 \%$ of the regional budget [16]. The legislation regarding the education budget in Indonesia has become the legal basis for policy holders at both the central and regional levels to be able to commit to investing in human resources through the education sector.

The education budget posture in recent years shows an upward trend. Based on data released by the Ministry of Finance, from 2015 to 2019 there was an increase in the education budget allocation, except in 2017 there was a decline of around 3 trillion. Sequentially, in 2015 the education budget was equivalent to 409.1 trillion, in 2017 amounting to 419.2 trillion, in 2016 amounting to 416.1 trillion, in 2018 amounting to 444.1 trillion and in 2019 budgeted at 492.5 trillion. In 2019 , the Indonesian government focuses on the state budget to encourage investment and competitiveness through the development of human resources [17].

In the 2019 State Budget Plenary Meeting, the government not only prioritized physical investment, but also investment in human resources by improving its quality. Good quality resources are fostered with good education. The government 
encourages various policy breakthroughs to improve the quality of human resources capable of competing in the international world. One way is to increase the education budget. The education budget allocation is used for school operational assistance, scholarships, employee salaries, and the construction or rehabilitation of educational infrastructure.

To identify the effectiveness of investment policies in human resources through the development of educational programs, certainly not only seen from the amount of the education sector budget that has been allocated, but the implementation and evaluation process. It needs to be monitored and monitored in an integrated manner in implementing the education sector's development priorities. The amount of the education budget is not only for employee expenditure or infrastructure improvements, but also to boost student competency and integrity as the successor of the nation's struggle.

\section{CONCLUSION}

Education is an important factor for preparing human resources in a country in order to compete in the global era. The concept of education as an investment has developed for a long time, which is believed that the development of the education sector in a country is an important factor that drives growth in other development sectors. Investment in human resources will be able to encourage increased national competitiveness, as a contribution to socio-economic development through increasing knowledge, skills, attitudes and productivity.

Based on the human development index in Indonesia released by the United Nations Development Program (UNDP), where Indonesia is still lagging behind other ASEAN countries, the priority of national programs is needed in developing Indonesian human resources in an integrated and comprehensive manner. The entrance to build capacity and integrity of human resources is nothing but through the education sector.
The Indonesian government has a strong commitment through development policies and investment in human resources through education, which is reinforced by a legal basis and an education budget allocation of $20 \%$. However, the existing strategic plan needs to be accompanied by an effective and integrated implementation and supervision process, so that national development goals can be achieved properly.

\section{REFERENCES}

[1] M.S. Iman, Pendidikan Partisipatif. Yogyakarta: Safiria Insani Press, 2004.

[2] H. Hendarmin \& M. Kartika, "The Relationship Between Human Capital and the Regional Economy Productivity," JEJAK: Jurnal Ekonomi dan Kebijakan, vol. 12, no. 1, pp. 138-140, March 2019.

[3] N. Martono, Sociology of Social Change; Classical, Modern, Posmodern, and Postcolonial Perspectives. Jakarta: PT RajaGrafindo Persada, 2012.

[4] B. Alic, "Investment in Human Capital - Prerequisite for The Growth of The Organizational Performance," ACADEMICA BRANCUSI, vol. 1, no. 2, pp. 66, 2018.

[5] H.D. Atmanti, "Investasi Sumber Dayama Manusia Melalui Pendidikan," Jurnal Dinamika Pembangunan, vol 2, no. 1, pp. 30, July 2005.

[6] D. Neamtu, "Education-Investment in Human Capital," Journal of Economics and Business Research, vol. 18, no. 2, pp. 150-160, 2012.

[7] M. Hasan \& M. Aziz, Pembangunan Ekonomi \& Pemberdayaan Masyarakat; Strategi Pembangunan Manusia dalam Perspektif Ekonomi Lokal. CV. Nur Lina, 2018.

[8] S. Nurjanah, "Human Capital dan Peranan Pemerintah dalam Pendidikan, "EconoSains, vol. 12, no. 1, pp. 83-84, 2014.

[9] S. Nurjanah, "Human Capital dan Peranan Pemerintah dalam Pendidikan, "EconoSains, vol. 12, no. 1, pp. 85, 2014.

[10] A. Idi, Sosiologi Pendidikan. Jakarta: PT RajaGrafindo Persada, 2013.

[11] Nurkolis, Pendidikan sebagai Investasi Jangka Panjang. http://artikel.us/ nurkolis5.html, 2002.

[12] A.M. Ngandoh, "Aspek Ekonomi Pendidikan dalam Pengembangan Sumber Daya Manusia,” AKMEN Jurnal Ilmiah, vol. 9, no. 1, pp. 63-64, 2012.

[13] E. Rosalin, "Konsep Human Investment dalam Konteks Pembangunan Masyrakat," Jurnal Manajemen Pendidikan, vol. 2, no.2, pp. 15, 2006.

[14] htpp://www.hdr.undp.org

[15] htpp://www.bps.go.id

[16] The Act Number 20 Year 2003 on the National Education System

[17] htpp://www.kemenkeu.go.id 